\title{
URGENSI PEMIDANAAN TERHADAP PENGENDALI KORPORASI YANG TIDAK TERCANTUM DALAM KEPENGURUSAN
}

Kajian Putusan Nomor 1081 K/PID.SUS/2014

\section{URGENCY OF SENTENCING TO THE UNREGISTERED CORPORATE CONTROLLER IN DECEPTIONS}

\author{
An Analysis of Court Decision Number 1081 K/PID.SUS/2014
}

\author{
Budi Suhariyanto \\ Pusat Penelitian dan Pengembangan Hukum dan Peradilan MA RI \\ Jl. Jend. Ahmad Yani Kav. 58 Jakarta Pusat 10510 \\ E-mail: penelitihukumma@gmail.com
}

\begin{abstract}
Naskah diterima: 3 Oktober 2017; revisi: 6 November 2017; disetujui 18 Desember 2017
http://dx.doi.org/10.29123/jy.v10i3.240
\end{abstract}

\begin{abstract}
ABSTRAK
Kejahatan korporasi saat ini tidak hanya dapat dilakukan oleh orang yang berada dalam struktur organisasi, tetapi pengendalinya bisa dilakukan oleh orang yang tidak tercantum dalam kepengurusan. Perundang-undangan tidak mengatur secara jelas bahwa pengendali korporasi yang berada di luar struktur organisasi dapat dijerat pemidanaan. Putusan Nomor 1081 K/PID.SUS/2014 menjatuhkan pidana terhadap pengendali korporasi yang tidak tercantum dalam kepengurusan. Menarik dipermasalahkan yaitu bagaimana urgensi pemidanaan terhadap pengendali korporasi yang tidak tercantum dalam kepengurusan. Metode penelitian normatif digunakan untuk menjawab permasalahan tersebut. Dari hasil pembahasan disimpulkan bahwa hanya undang-undang tentang pencucian uang dan undangundang tentang pendanaan terorisme yang mengatur tentang pengendali korporasi, tetapi pengaturannya masih belum jelas dalam mengidentifikasi pengendali korporasi yang tidak tercantum dalam kepengurusan. Putusan Nomor 1081 K/PID.SUS/2014 memberikan penjelasan hukum bahwa termasuk personel pengendali korporasi adalah seseorang yang tidak tercantum dalam
\end{abstract}

struktur kepengurusan tetapi mempunyai kekuasaan dan kewenangan yang sangat menentukan dalam pengambilan keputusan perusahaan. Melalui kaidah hukum tersebut, Mahkamah Agung berhasil mengisi kekosongan hukum atas ruang lingkup personel pengendali korporasi di luar struktur kepengurusan. Putusan ini dapat dijadikan yurisprudensi dalam rangka efektivitas penanggulangan tindak pidana korporasi di Indonesia.

Kata kunci: pemidanaan, pengendali, tindak pidana korporasi.

\section{ABSTRACT}

Corporate crime is now not only committed by the persons recorded in an organizational structure, but the controller can be done by people who are not recorded in the organization. The legislation does not set clearly that corporate controllers outside the organizational structure can be charged with criminal prosecution. Supreme Court Decision Number 1081 K/PID. SUS/2014 imposed a sentence against the corporate controllers that are not recorded in the organization. It is 
interesting to focus on the urgency of sentencing against unrecorded corporate controllers in the management of the organization. The normative research method is used in this analysis to see the sights of the problem. As of the discussion it is concluded that only Law on Money Laundering and Law on Terrorism regulating on the issue of corporate controller, yet still inexplicit in identifying the corporate controllers unrecorded in the management of organizational structure. The Court Decision Number 1081 K/PID.SUS/2014 provides the legal explanation stating that someone who is not included in the corporate governance structure but has the power and authority that is crucial in corporate decision-making is called the corporate controller. Through the rule of law, the Supreme Court has been successfully fills a legal vacuum on the scope of the corporate control of personnel outside the management structure. This ruling can be used as jurisprudence in the framework of effectiveness of the prevention of corporate crime in Indonesia.

Keywords: sentencing, controller, corporate crime.

antara satu undang-undang dengan yang lainnya adalah berbeda-beda (Sjawie, 2013: 329). Dapat dikatakan bahwa integralitas sistem pemidanaan terhadap korporasi dalam perundang-undangan dinilai kurang jelas.

Kurang jelasnya pengaturan pemidanaan korporasi ini kemudian dijadikan celah oleh para pelaku tindak pidana korporasi untuk keluar atau menghindar dari pertanggungjawaban pidana. Dalam hal penetapan pelaku tindak pidana korporasi yang umumnya menurut perundang-undangan tersebut direpresentasikan oleh pengurus atau karyawan yang memiliki kedudukan di dalam struktur dan melakukan tindakannya untuk kepentingan korporasi.

Secara de facto dalam praktik penegakan siapa yang bertanggung jawab di antara mereka yang menjadi pengurus atau yang termasuk dalam lingkungan suatu perusahaan yang melakukan perbuatan pidana (Sutedi, 2015: 40).

Kurang lebih terdapat seratus perundangundangan yang mengatur korporasi sebagai subjek hukum, tetapi dari keseluruhannya mengandung keragaman dalam mengatur pemidanaan korporasi. Misalnya dalam hal penentuan definisi, ruang lingkup tanggung jawab, jenis sanksi, dan hukum acara pidana korporasi hukum, terdapat seseorang yang tidak tercantum dalam kepengurusan tetapi mempunyai kendali dan melakukan kejahatan dengan korporasi. Hal ini merupakan modus operandi baru bahwa kejahatan korporasi saat ini tidak hanya dapat dilakukan oleh orang yang berada dalam struktur organisasi, tetapi pengendalinya bisa dilakukan oleh orang yang tidak tercantum dalam kepengurusan. Konsekuensi logisnya (secara positivis) maka terhadapnya tidak dapat dituntut pertanggungjawaban pidana korporasi. 
Perundang-undangan tidak mengatur secara jelas bahwa pengendali korporasi yang berada di luar struktur organisasi dapat dijerat pemidanaan. Mahkamah Agung melalui Putusan Nomor 1081 K/PID.SUS/2014 telah memberikan penafsiran terhadap pengendali korporasi yang berada di luar struktur organisasi atau dengan kata lain ia bertindak tidak dalam otorisasi (atasan) pengurus korporasi.

Mahkamah Agung menjatuhkan pidana terhadap LS karena dinilai sebagai pengendali korporasi, meskipun yang bersangkutan tidak tercantum dalam (struktur) kepengurusan. LS awalnya didakwa melakukan tindak pidana kehutanan sebagaimana diatur Pasal 78 ayat (5) jo. Pasal 50 ayat (3) huruf f Undang-Undang Nomor 19 Tahun 2004 tentang Kehutanan jo. Pasal 55 ayat (1) ke-I KUHP, tindak pidana migas sebagaimana diatur Pasal 53 huruf $b$ Undang-Undang Nomor 22 Tahun 2001 tentang Minyak dan Gas Bumi jo. Pasal 55 ayat (1) ke-I KUHP, tindak pidana pencucian uang Pasal 3 ayat (1) huruf c Undang-Undang Tindak Pidana Pencucian Uang dan Pasal 3 Undang-Undang Pencegahan dan Pemberantasan Tindak Pidana Pencucian Uang. Terhadap dakwaan tersebut, jaksa penuntut umum menuntut LS dengan pidana penjara selama 15 tahun dan denda sebesar Rp100.000.000,- subsider sepuluh bulan kurungan.

Putusan Nomor 145/PID.B/2013/PN.SRG membebaskan LS dari dakwaan tindak pidana pencucian uang dan menyatakan LS terbukti secara sah dan meyakinkan bersalah melakukan tindak pidana "secara bersama-sama dengan sengaja membeli hasil hutan yang diketahui berasal dari kawasan hutan yang diambil secara tidak sah" dan tindak pidana "secara bersamasama melakukan pengangkutan bahwa bakar minyak tanpaizinusahapengangkutan"karenanya menjatuhkan pidana penjara selama dua tahun dan denda sebesar Rp50.000.000,- dengan ketentuan apabila denda tidak dibayar maka diganti dengan pidana kurungan selama enam bulan. Di tingkat banding, dalam Putusan Nomor 15/PID/2014/ PT.JPR membatalkan Putusan Nomor 145/ PID.B/2013/PN.SRG, mengadili sendiri dan menghukum LS dengan pidana penjara delapan tahun dan denda sebesar Rp50.000.000,- dengan ketentuan apabila denda tidak dibayar maka diganti dengan pidana kurungan selama enam bulan. Menurut pengadilan tinggi, LS terbukti secara sah dan meyakinkan:

1. Secara bersama-sama dengan sengaja membeli hasil hutan yang diketahui berasal dari kawasan hutan yang diambil secara tidak sah;

2. Secara bersama-sama melakukan pengangkutan bahan bakar minyak tanpa izin usaha pengangkutan;

3. Dengan sengaja membayarkan atau membelanjakan harta kekayaan yang diketahuinya atau patut diduganya merupakan hasil tindak pidana;

4. Menempatkan dan mentransfer mata uang yang diketahui atau patut diduganya merupakan hasil tindak pidana dengan tujuan menyamarkan asal-usul harta kekayaan.

Pada tingkat kasasi, dalam Putusan Nomor 1081 K/PID.SUS/2014 membatalkan Putusan Nomor 15/PID/2014/PT.JPR yang membatalkan Putusan Nomor 145/PID.B/2013/ PN.SRG. Mahkamah Agung mengadili sendiri dan menyatakan LS terbukti secara sah dan meyakinkan bersalah melakukan tindak pidana: 
1) secara bersama-sama dengan sengaja membeli hasil hutan yang diketahui berasal dari kawasan hutan yang diambil secara tidak sah;2) secara bersama-sama melakukan pengangkutan bahan bakar minyak tanpa izin usaha pengangkutan; 3) dengan sengaja membayarkan atau membelanjakan harta kekayaan yang diketahuinya atau patut diduganya merupakan hasil tindak pidana; 4) menempatkan dan mentransfer mata uang yang diketahui atau patut diduganya merupakan hasil tindak pidana dengan tujuan menyamarkan asal-usul harta kekayaan. Mahkamah Agung memutuskan menjatuhkan pidana kepada LS dengan pidana penjara 15 tahun dan denda sebesar Rp5.000.000.000,dengan ketentuan apabila denda tidak dibayar maka diganti dengan pidana kurungan selama satu tahun.

Dasar pertimbangan hukum majelis hakim kasasi dalam memberikan penjeratan atas tindak pidana pencucian uang terhadap LS adalah karena LS selaku personel pengendali korporasi. Dinyatakan bahwa meskipun nama terdakwa tidak tercantum di dalam akta pendirian perusahaan CV LBT dan UD MR serta PT R, melainkan atas nama orang lain. Namun dalam kenyataannya atau secara de facto LS mempunyai kekuasaan dan kewenangan yang sangat signifikan dan sangat menentukan dalam pengambilan keputusan dan kebijakan perusahaan.

Setiap kali pengambilan keputusan atau kebijakan perusahaan selalu berkoordinasi dan meminta petunjuk dari LS. LS yang menentukan setiap langkah dan keputusan yang akan diambil oleh pimpinan perusahaan. Direktur utama dan direktur serta komisaris hanya formalitas belaka. Melalui kendalinya tersebut, korporasi-korporasi tersebut melakukan berbagai pelanggaran dan kejahatan yaitu tindak pidana kehutanan, pencucian uang, dan penyelundupan bahan bakar minyak.

Pertimbangan hukum Mahkamah Agung di atas, menarik untuk dikaji karena telah memberikan sebuah penjelasan tentang kedudukan pengendali korporasi yang tidak tercantum dalam kepengurusan korporasi. Mengingat bahwa perundang-undangan tidak mengatur personel pengendali korporasi yang tidak tercantum dalam kepengurusan. Secara de jure, perundang-undangan (Undang-Undang Nomor 8 Tahun 2010 tentang Pencegahan dan Pemberantasan Tindak Pidana Pencucian Uang) hanya mengatur personel pengendali korporasi dalam konstruksi "otoritas atasan" atau sesuai (dalam) struktur organisasi. Pada perkara LS ini, Mahkamah Agung telah melakukan penafsiran hukum guna menjatuhkan putusan pemidanaan terhadap pengendali korporasi yang tidak tercantum dalam kepengurusan. Dapat dikatakan bahwa Mahkamah Agung berupaya mengisi kekosongan hukum terkait pertanggungjawaban pidana personel pengendali korporasi yang tidak tercantum dalam struktur kepengurusan.

\section{B. Rumusan Masalah}

Berdasarkan uraian latar belakang di atas maka dalam penelitian ini mempermasalahkan yaitu bagaimanakah urgensi pemidanaan terhadap pengendali korporasi yang tidak tercantum dalam kepengurusan pada Putusan Nomor 1081 K/PID. SUS/2014?

\section{Tujuan dan Kegunaan}

Tujuan dari penelitian ini adalah untuk menganalisis eksistensi pemidanaan pengendali 
korporasi menurut perundang-undangan dan urgensi pemidanaan terhadap pengendali korporasi yang tidak tercantum dalam kepengurusan. Adapun kegunaan yang diperoleh secara praktis adalah untuk memberikan pengetahuan dan pemahaman bagi penegak hukum khususnya hakim dalam menghadapi perkara yang terkait dengan personel pengendali korporasi serta bagi pembentuk undang-undang dalam rangka melakukan pembaruan hukum pidana yang terkait kebijakan kriminalisasi personel pengendali korporasi di masa yang akan datang.

\section{Tinjauan Pustaka}

Pada dasarnya pidana memberikan nestapa kepada pembuat delik. Namun, penjatuhan pidana yang mengakibatkan nestapa bukanlah tujuan utama dari pidana, melainkan masih terdapat upaya melalui tindakan-tindakan. Hukum pidana menentukan perbuatan-perbuatan apa yang perlu diancam dengan hukum pidana dan jenis pidana serta cara penerapannya sehingga kedudukan sanksi sangatlah penting (Alim et al., 2013: 19-20). Walaupun pembentuk undang-undang memberikan kebebasan menentukan batas maksimal dan minimal lama (sanksi) pidana yang harus dijalani terdakwa, hal ini bukan berarti hakim dapat dengan seenaknya menjatuhkan pidana tanpa dasar pertimbangan yang lengkap. Pada hakikatnya, putusan pemidanaan merupakan putusan hakim yang berisikan suatu perintah kepada terdakwa untuk menjalani hukuman atas perbuatan yang dilakukannya sesuai dengan amar putusan (Mulyadi, 2010: 126).

Awalnya pemidanaan hanya diperuntukkan subjek hukum individu/manusia, seiring perkembangan masyarakat di mana korporasi/ badan hukum juga dapat melakukan kejahatan maka perundang-undangan mulai menetapkan korporasi sebagai subjek tindak pidana. Secara doktrin, kejahatan korporasi dapat dibedakan menjadi tiga bentuk yaitu crimes for corporation, crimes against corporation, dan criminal corporations. Crimes for corporation adalah kejahatan korporasi yang dilakukan untuk kepentingan korporasi dan bukan sebaliknya (corporate crime are clearly commited for the corporate and not against).

Crimes against corporation adalah kejahatanyang dilakukan olehkaryawan korporasi itu sendiri terhadap korporasi tempatnya bekerja. Adapun criminal corporations adalah korporasi yang sengaja dibentuk dan dikendalikan untuk melakukan kejahatan (Hiariej, 2014: 156). Dipidananya korporasi dengan ancaman pidana adalah salah satu upaya untuk menghindari tindakan pemidanaan terhadap para pegawai korporasi itu sendiri (Dix \& Gilbert, 1979: 43).

Memang hingga saat ini KUHP masih belum menempatkan korporasi sebagai subjek hukum pidana. Akan tetapi berbagai peraturan perundang-undangan yang ada di luar KUHP telah mengakui dan menempatkan korporasi sebagai subjek hukum pidana di samping manusia (Sjawie, 2013: 312). Di antara perundangundangan di luar KUHP yang mengatur korporasi sebagai subjek hukum pidana (selain orang/individu/manusia) adalah Undang-Undang Pencegahan dan Pemberantasan Tindak Pidana Pencucian Uang.

Pasal 1 angka 10 Undang-Undang Pencegahan dan Pemberantasan Tindak Pidana Pencucian Uang mendefinisikan korporasi sebagai kumpulan orang dan/atau kekayaan yang terorganisir, baik merupakan badan hukum 
maupun bukan badan hukum. Berbeda dengan korporasi dalam subjek hukum perdata yang hanya diartikan sebagai badan hukum. Dalam hukum pidana, pengertian korporasi bukan hanya yang berbadan hukum, tetapi juga yang tidak berbadan hukum. Dengan demikian cakupan korporasi dalam hukum pidana jauh lebih luas dibandingkan dengan konsep badan hukum yang terdapat dalam konsep hukum perdata (Kristian, 2014: 53).

Diterimanya korporasi dalam pengertian badan hukum atau konsep pelaku fungsional (functional daderschap) dalam hukum pidana merupakan perkembangan yang sangat maju dengan menggeser doktrin yang mewarnai wetboek van strafrecht (KUHP) yakni "universitas delinguere non potest" atau "societas dellinguere non potest" yaitu badan hukum tidak dapat melakukan tindak pidana (Efendy, 2012: 83). Konsekuensi logis atas ditetapkannya korporasi sebagai subjek tindak pidana maka terhadapnya dapat dituntutkan pertanggungjawaban pidana.

Pertanggungjawaban pidana korporasi ini didasarkan pada doktrin respondeat superior yaitu suatu doktrin yang menyatakan bahwa korporasi sendiri tidak dapat melakukan kesalahan. Dalam hal ini, hanya agen-agen korporasi yang dapat melakukan kesalahan, yakni mereka yang bertindak untuk dan atas nama korporasi (Kristian, 2014: 54).

Secara normatif, agen korporasi dalam suatu perseroan adalah jajaran direksi. Direksi adalah yang berwenang untuk melakukan pengurusan perseroan dan berwenang mewakili perseroan untuk segala tindakan yang harus dijalankan untuk dan atas nama perseroan, baik untuk tindakan intern maupun untuk tindakan ekstern, termasuk untuk mewakili perseroan di pengadilan. Dalam menjalankan tugasnya, direksi diawasi oleh komisaris. Selain direksi dan komisaris, organ lainnya adalah RUPS (Rapat Umum Pemegang Saham) yang memiliki wewenang paling tinggi dan bertugas untuk menentukan arah dan tujuan perseroan berdiri.

Saat ini berkembang modus operandi kejahatan yaitu korporasi ditempatkan sebagai sarana untuk melakukan kejahatan, atau sebagai “topeng” untuk menyembunyikan wajah asli dari suatu kejahatan tersebut. Pemimpin korporasi di sini hanya melaksanakan tugas berdasarkan pembagian pekerjaan yang telah ditentukan oleh para penjahat yang membuat korporasi dengan tujuan menutupi kejahatan tersebut (Hiariej, 2014: 157). Jajaran kepengurusan korporasi tersebut sama sekali tidak memiliki kewenangan dan kekuasaan untuk menentukan kebijakan korporasi. Artinya directing mind and will korporasi tidak berkedudukan sebagai pengurus atau termasuk dalam struktur korporasi.

Kejahatankorporasidenganmodeldemikian menunjukkan karakteristiknya sebagai white collor crime yang memanfaatkan celah hukum untuk melepaskan diri dari pertanggungjawaban pidana. Mereka menjadi pengendali korporasi yang telah terbukti melakukan perbuatan melawan hukum (menyamarkan aset hasil tindak pidana).

\section{Undang-Undang Perseroan Terbatas,} tidak dapat menjangkau perbuatan personel pengendali perseroan, kecuali direksi, anggota dewan komisaris, dan para pemegang saham (Atmasasmita, 2014: 43-44). Terhadap para penjahat pengendali korporasi yang tidak terdapat dalam susunan kepengurusan perseroan tersebut, sulit untuk dijerat dengan pertanggungjawaban hukum. 


\section{METODE}

Metode penelitian yang digunakan adalah penelitian normatif dengan menggunakan tiga pendekatan yaitu pendekatan perundangundangan (statute approach), pendekatan kasus (case approach), serta pendekatan konseptual (conceptual approach). Pendekatan perundangundangan digunakan untuk mengkaji masalah secara normatif baik dari perspektif ius constitutum maupun ius constituendum terkait pemidanaan korporasi.

Pendekatan kasus digunakan untuk mengkaji masalah dari segi praktik peradilan yang berkembang dalam merespon dan mengaktualisasikan hukum secara in concreto. Pendekatan konseptual digunakan untuk mengkaji masalah visi pembaruan hukum terkait pemidanaan korporasi dalam pertimbangan hukum yang tercantum pada putusan pengadilan dihubungkan dengan pandangan dan doktrindoktrin ahli hukum (Panggabean, 2014: 170).

Sumber data yang digunakan adalah data sekunder yang terdiri atas bahan hukum primer berupa peraturan perundang-undangan dan putusan pengadilan, serta bahan hukum sekunder berupa literatur dan hasil penelitian. Bahanbahan hukum dan literatur tersebut dikumpulkan melalui metode sistematis dan dicatat dalam kartu antara lain permasalahannya, asas-asas, argumentasi, implementasi yang ditempuh, alternatif pemecahannya, dan lain sebagainya. Data yang telah dikumpulkan kemudian dideskripsikan dan diinterpretasikan sesuai pokok permasalahan selanjutnya disistematisasi, dieksplanasi, dan diberikan argumentasi. Metode analisis yang diterapkan untuk mendapatkan kesimpulan atas permasalahan yang dibahas adalah melalui analisis yuridis kualitatif.

\section{HASIL DAN PEMBAHASAN}

Sejatinya eksistensi korporasi menjadi salah satu tulang punggung ekonomi dunia, akan tetapi dalam perjalanan selanjutnya, korporasi cenderung melakukan hal-hal yang tidak sesuai dengan etika dan melanggar hukum untuk berkompetisi dalam persaingan ekonomi global dengan tujuan mencari keuntungan yang sebesar-besarnya. Motivasi pencarian keuntungan inilah yang akhirnya mendorong korporasi untuk melakukan suatu tindakan unfair competition yang mengarah pada tindakan hukum terutama yang menyangkut kejahatan korporasi (Panggabean, 2017: 8). Dalam hal pertanggungjawaban atas terjadinya tindak pidana korporasi maka penjatuhan pidana dapat dijatuhkan terhadap pengurus dan/atau kuasa pengurus maupun terhadap korporasi. Namun demikian pertanggungjawaban pidana pengurus dibatasi sepanjang pengurus mempunyai kedudukan fungsional dalam struktur organisasi korporasi (Ginting, 2012: 14).

Pada perkara korupsi misalnya, dalam hal tindak pidana korupsi dilakukan oleh atau atas nama suatu korporasi, maka tuntutan dan penjatuhan pidana dapat dilakukan terhadap korporasi dan atau pengurusnya. Tindak pidana korupsi dilakukan oleh korporasi apabila tindak pidana tersebut dilakukan oleh orang-orang baik "berdasarkan hubungan kerja" maupun "berdasarkan hubungan lain," bertindak dalam lingkungan korporasi tersebut baik sendiri maupun bersama-sama (Pasal 20 ayat (1) jo. Pasal 20 ayat (2) Undang-Undang Tindak Pidana Korupsi).

Adapun yang dimaksud dengan "orangorang berdasarkan hubungan kerja" adalah orang-orang yang memiliki hubungan kerja 
sebagai pengurus atau pegawai, yaitu: a) berdasarkan anggaran dasar dan perubahannya; b) berdasarkan kepangkatan sebagai pegawai dan perjanjian kerja dengan koporasi; c) berdasarkan surat pengangkatan sebagai pegawai; dan d) berdasarkan perjanjian kerja sebagai pegawai. Sedangkan yang dimaksud dengan "orang-orang berdasarkan hubungan lain" adalah orang-orang yang memiliki hubungan lain selain hubungan kerja dengan korporasi, antara lain mewakili korporasi untuk melakukan perbuatan hukum untuk dan atas nama korporasi berdasarkan: 1) pemberian kuasa; 2) perjanjian dengan pemberi kuasa (pemberi kuasa bukan diberikan dengan surat kuasa tersendiri tetapi dicantumkan dalam perjanjian sehingga merupakan bagian yang tidak terpisahkan dari perjanjian tersebut); dan 3) pendelegasian wewenang (Sjahdeni, 2006: 151). Apabila orang-orang yang berdasarkan hubungan kerja dan/atau hubungan lain bertindak sudah diluar atau tidak lagi dalam batas-batas atau tugas korporasi, maka korporasi tidak dapat dimintakan pertanggungjawaban pidana (Mugopal, 2016: 6).

Tindakan hukum untuk menetapkan korporasi sebagai subjek hukum tindak pidana tidak berarti meniadakan pertanggungjawaban pidana yang dilakukan oleh pengurusnya, namun merupakan bentuk perluasan pertanggungjawaban pidana sehingga baik pengurus korporasi maupun korporasi itu sendiri dapat dimintai pertanggungjawaban pidana secara bersama-sama tetapi tidak dalam kerangka ajaran penyertaan (deelneming). Sebaliknya dalam hal induk perusahaan dengan anak perusahaan, atau hubungan hukum konsorsium/KSO dalam kegiatan yang berimplikasi pidana korupsi, maka kualitas hubungan hukum antara dua atau lebih badan hukum dapat dikualifisir pada ajaran penyertaan sebagai yang melakukan atau turut serta melakukan di antara sesama korporasi sebagai subjek hukum pidana (Mugopal, 2016: 9-10).

Secara normatif, Undang-Undang Tindak Pidana Korupsi tidak mengatur secara spesifik dan tegas mengenai personel pengendali korporasi. Pengaturan secara eksplisit tentang personel pengendali korporasi terdapat pada Undang-Undang Pencegahan dan Pemberantasan Tindak Pidana Pencucian Uang dan UndangUndang Pendanaan Terorisme. Pasal 1 angka 4 Undang-Undang Pencegahan dan Pemberantasan Tindak Pidana Pencucian Uang dan Pasal 1 angka 13 Undang-Undang Pendanaan Terorisme yang mendefinisikan personel pengendali korporasi, yaitu setiap orang yang memiliki kekuasaan atau wewenang sebagai penentu kebijakan korporasi atau memiliki kewenangan untuk melakukan kebijakan korporasi tersebut tanpa harus mendapat otorisasi atasannya. Menurut Pasal 6 ayat (2) Undang-Undang Pencegahan dan Pemberantasan Tindak Pidana Pencucian Uang, pidana dijatuhkan terhadap korporasi apabila tindak pidana pencucian uang itu:

a. Dilakukan atau diperintahkan oleh personel pengendali korporasi;

b. Dilakukan dalam rangka pemenuhan maksud dan tujuan korporasi;

c. Dilakukan sesuai dengan tugas dan fungsi pelaku atau pemberi perintah; dan

d. Dilakukan dengan maksud memberikan manfaat bagi korporasi.

Formulasi Pasal 6 ayat (2) Undang-Undang Pencegahan dan Pemberantasan Tindak Pidana 
Pencucian Uang di atas berpotensi menimbulkan permasalahan dalam praktik penegakan hukum, karena dalam penjelasan tidak ada penjelasan terkait apakah persyaratan sebagaimana dimaksud itu bersifat kumulatif artinya harus memenuhi keempat syarat tersebut secara bersamaan, yaitu: a) dilakukan atau diperintahkan oleh personel pengendali korporasi; b) dilakukan dalam rangka pemenuhan maksud dan tujuan korporasi; c) dilakukan sesuai dengan tugas dan fungsi pelaku atau pemberi perintah; dan d) dilakukan dengan maksud memberikan manfaat bagi korporasi. Artinya secara keseluruhan harus terpenuhi untuk dapat diterapkan pertanggungjawaban pidana dengan subjek hukum korporasi atau yang dimaksudkan adalah bersifat alternatif, artinya dengan terpenuhinya salah satu syarat saja maka pertanggungjawaban pidana korporasi dapat diterapkan (Kristiana, 2015: 194).

Ditetapkannya pengurus saja sebagai yang dapat dipidana ternyata tidak cukup. Dalam delik ekonomi bukan mustahil denda yang dijatuhkan sebagai hukuman kepada pengurus dibandingkan dengan keuntungan yang telah diterima oleh korporasi dengan melakukan perbuatan itu atau kerugian yang ditimbulkan dalam masyarakat, atau yang diderita oleh saingannya. Keuntungan dan/atau kerugian itu adalah lebih besar daripada denda yang dijatuhkan sebagai pidana.

Dipidananya pengurus tidak memberikan jaminan yang cukup bahwa korporasi tidak sekali lagi melakukan perbuatan yang telah dilarang oleh undang-undang itu. Ternyata dipidananya pengurus saja tidak cukup untuk mengadakan represi terhadap delik oleh atau dengan suatu korporasi. Karenanya diperlukan pula untuk dimungkinkan memidana korporasi, dan pengurus atau pengurus saja (Tambunan, 2016: 117).
Berkaitan dengan pidana pokok yang dapat dijatuhkan terhadap korporasi adalah pidana denda. Selain pidana pokok, hakim dapat menjatuhkan pidana tambahan berupa pengumuman putusan hakim, pembekuan sebagian atau seluruh kegiatan usaha korporasi, pencabutan izin usaha, pembubaran dan/atau pelarangan korporasi, perampasan aset korporasi untuk negara, dan/atau pengambilalihan korporasi oleh negara (Pasal 7 ayat (1) dan (2) UndangUndang Pencegahan dan Pemberantasan Tindak Pidana Pencucian Uang). Dalam hal korporasi tidak mampu membayar pidana denda maka pidana denda tersebut diganti dengan perampasan harta kekayaan milik korporasi atau personel pengendali korporasi yang nilainya sama dengan putusan pidana denda yang dijatuhkan. Bilamana penjualan harta kekayaan milik korporasi yang dirampas tidak mencukupi, pidana pengganti denda dijatuhkan terhadap personel pengendali korporasi dengan memperhitungkan denda yang telah dibayar (Pasal 9 Undang-Undang Pencegahan dan Pemberantasan Tindak Pidana Pencucian Uang).

Sistem pertanggungjawaban pidana korporasi pada tindak pidana pencucian uang dapat dibagi menjadi empat sistem pertanggungjawaban pidana yaitu: Pertama, korporasi yang bertindak sebagai pelaku tindak pidana maka korporasi sendiri yang harus memikul pertanggungjawaban pidana. Kedua, korporasi sebagai pelaku maka personel pengendali korporasi (pengurus korporasi) yang harus memikul pertanggungjawaban pidana. Ketiga, korporasi bersama dengan personel pengendali korporasi sebagai pelaku dan keduanya harus memikul pertanggungjawaban pidana. Keempat, pengurus korporasi berperan sebagai pelaku tindak pidana pencucian uang 
maka beban pertanggungjawaban pidananya hanya dibebankan kepada pengurus korporasi saja (Sjahdeni, 2006: 59).

Apabila pengurus korporasi bertindak tidak untuk dan atas nama korporasi, maka pertanggungjawaban pidananya hanya dibebankan kepada pengurus korporasinya itu sendiri. Kemudian apabila pengurus korporasi (personel pengendali korporasi) bertindak untuk dan atas nama korporasi (bersama-sama dengan korporasi), maka pertanggungjawabannya dapat dibebankan kepada korporasi dan pengurus korporasi itu sendiri (Amalia, 2016: 399).

Korporasi tidak dapat dikenakan pertanggungjawaban pidana apabila directing mind and will korporasi melakukan tindak pidana terhadap korporasi mereka sendiri dan korporasi yang bersangkutan telah melakukan penuntutan terhadap tindakan directing mind and will-nya. Syarat ini sekaligus menandakan bahwa tindak pidana yang dilakukan para pihak tersebut (termasuk personel pengendali korporasi) baru diatributkan kepada korporasi bila tindakannya memberikan manfaat atau keuntungan bagi korporasi (Sudirman \& Feronica, 2011: 302).

Secara terminologi, personel pengendali korporasi merupakan pengembangan berkaitan dengan pertanggungjawaban pidana korporasi. Hal ini memungkinkan untuk menetapkan dan menentukan "orang" dalam korporasi untuk menjadi terdakwa apabila korporasi terlibat dalam kejahatan pencucian uang. Dengan jeli, jaksa penuntut umum mengaitkan perbuatan LS dalam melakukan tindak pidana kehutanan dan migas dengan tindak pidana pencucian uang sehingga jerat terhadapnya mengarah kepada personel pengendali korporasi sebagaimana dimaksud oleh Undang-Undang Nomor 8 Tahun 2010.
Susunan dakwaan kepada LS secara komulatif dengan dakwaan kesatu dan kedua adalah kejahatan asal, dakwaan ketiga dan keempat adalah pencucian uang sangat tepat. Secara rinci dakwaan-dakwaan tersebut berupa perbuatan:

1. Secara bersama-sama dengan IM sebagai orang yang melakukan atau turut serta melakukan yakni dengan sengaja menerima, membeli atau menjual, menerima tukar, menerima titipan, menyimpan atau memiliki hasil hutan diketahui atau patut diduga berasal dari kawasan hutan yang diambil atau dipungut secara tidak sah.

2. Secara bersama-sama dengan JL sebagai orang yang melakukan atau turut serta melakukan yakni telah melakukan pengangkutan tanpa memiliki izin usaha pengangkutan.

3. Dengan sengaja membayarkan atau membelanjakan harta kekayaan yang diketahuinya atau patut diduganya merupakan hasil tindak pidana, baik perbuatan itu atas namanya sendiri maupun atas nama pihak lain dengan maksud menyembunyikan atau menyamarkan asalusul harta kekayaan sehingga seolah-olah menjadi harta kekayaan yang sah.

4. Menempatkan, mentransfer, mengalihkan, membelanjakan, membayarkan, menghibahkan, menitipkan, membawa ke luar negeri, mengubah bentuk, menukarkan dengan mata uang atau surat berharga atau perbuatan lain atas harta kekayaan yang diketahuinya atau patut diduganya merupakan hasil tindak pidana dengan tujuan menyembunyikan atau menyamarkan asal-usul harta kekayaan, 
sebagaimana tercantum dalam dakwaan kesatu primer dan kedua dan ketiga.

Dakwaan kumulatif sebagaimana disusun di atas, memberikan penjeratan pertanggungjawaban pidana kepada LS secara sempurna dengan ditambahkan dakwaan tindak pidana pencucian uang. Selama ini salah satu sebab kegagalan upaya penegakan hukum dalam perkara mafia kehutanan disebabkan penegak hukumnya hanya menggunakan cara-cara biasa (ordinary) dalam menjerat pelaku kejahatan kehutanan. Pemerintah hanya menjerat pelaku mafia kehutanan dengan Undang-Undang Kehutanan yang terbukti memiliki kelemahan dan terbukti banyak pelaku yang lolos maupun divonis bebas di pengadilan.

Salah satu alternatif menjerat pelaku kejahatankehutananadalahmelakukanpendekatan multi door dengan mengupayakan penggunaan berbagai regulasi yang paling mungkin digunakan sesuai dengan prinsip-prinsip hukum pidana yang berlaku. Selain Undang-Undang Kehutanan, instrumen Undang-Undang Migas dan UndangUndang Pencegahan dan Pemberantasan Tindak Pidana Pencucian Uang merupakan cara yang lebih efektif untuk menangkap pelaku yang lebih utama yang tidak secara langsung terkait dengan tindakan kejahatan di level lapangan (Eddyono, 2017: 3) yaitu personel pengendali korporasi.

Harus diakui bahwa pendekatan normatif hukum pidana Indonesia sampai saat ini masih lekat pada pendekatan positivism hukum dengan paradigma keadilan retributif dengan tujuan utama penjeraan terhadap pelaku tindak pidana an sich (Atmasasmita, 2014: 214). Model penegakan hukum yang selama ini dilakukan, masih mengacu kepada penghukuman kepada pelaku daripada kepada aset dari hasil tindak pidana yang berhasil dikumpulkan. Kondisi tersebut kurang efektif karena aset hasil kejahatan masih dapat dimanfaatkan oleh pelaku kejahatan untuk tetap beraktivitas karena aset yang dimiliki tetap mampu menghidupi kegiatan, untuk itu selain penegakan hukum kepada pelaku, perampasan aset hasil dari tindak pidana yang merupakan live blood of the crime harus dapat diputus (cut off) sehingga tidak mampu lagi menghidupi aktivitasnya (Manthovani, 2013: 1).

Korporasi pelaku kejahatan memahami bahwa aset mereka adalah sumber kehidupan, maka mereka juga berlomba-lomba untuk mengamankan aset yang telah dimiliki agar tidak dapat disita oleh penegak hukum manakala terjadi penuntutan atas korporasinya. Dalam kondisi yang demikian tersebut terjadi usaha untuk membersihkan uang hasil tindak pidana agar terlihat bersih dan legal. Untuk menghadapi situasi seperti ini maka dibutuhkan aturan hukum yang dapat dijadikan pijakan oleh penegak hukum untuk merampas aset hasil tindak pidana. Aturan hukum tersebut adalah adanya Undang-Undang Pencegahan dan Pemberantasan Tindak Pidana Pencucian Uang (Manthovani, 2013: 1-2).

Rezim hukum tindak pidana pencucian uang berangkat dari pemidanaan yang berorientasi pada "asset" atau "follow the money." Dalam perspektif ini, pemidanaan berorientasi pada aset, itulah sebabnya pemulihan atas aset tindak pidana, pengembalian atas aset tindak pidana baik untuk kepentingan negara maupun pihak yang dirugikan menjadi salah satu tujuan utama, di samping juga untuk memutus mata rantai kejahatan (Kristiana, 2015: 15).

Pentingnya mengkaitkan antara kejahatan asal dengan pencucian uang adalah karena untuk merampas kembali hasil kejahatan yang dijarah pelaku dan sekaligus memidana pelaku baik yang 
terkait dengan kejahatan asal maupun kejahatan pencucian uangnya atau dengan kata lain, dengan menggunakan anti pencucian uang adalah merupakan strategi untuk tujuan penegakan hukum bukan saja untuk memidana pelaku tetapi juga merampas semua hasil kejahatan. Atau dalam tahap tertentu dapat dikatakan untuk mengungkap kejahatan asal bisa digunakan terlebih dahulu sangkaan Undang-Undang Pencegahan dan Pemberantasan Tindak Pidana Pencucian Uang, yang didalami dan berakhir pada didapatkannya bukti awal kejahatan asalnya, pada akhirnya dikatakan bahwa dengan adanya ketentuan anti pencucian uang diartikan sebagai mengungkap kejahatan bukan lagi dari hulu tetapi dilacak dari hilir (Ganarsih, 2016: 198). Namun demikian, mengupayakan penggunaan berbagai undangundang yang paling mungkin digunakan sesuai dengan prinsip-prinsip hukum pidana yang berlaku dan perkembangan fakta di lapangan ini tetaplah harus diutamakan (Manthovani, 2013: 19). Pendekatan yang demikian dikenal sebagai multi door.

Melalui pendekatan multi door tersebut penegak hukum diberikan peta jalan (rood map) penegakan hukum yang simultan, terstruktur, dan efektif dengan memaksimalkan seluruh potensi peraturan perundang-undangan sehingga meminimalisir terjadinya kegagalan dalam penyidikan dan penuntutannya. Di samping itu manfaat yang dapat diperoleh dari penggunaan pendekatan multi door adalah membuat jera para pelaku tindak pidana khususnya pelaku yang menjadi otak dari suatu kejahatan yang terorganisir (Manthovani, 2013: 19). Sebagaimana dakwaan dalam kasus LS menggabungkan tindak pidana kehutanan dan tindak pidana migas dengan tindak pidana pencucian uang merupakan langkah yang tepat dari jaksa penuntut umum. Ketepatan tersebut dikarenakan didakwakannya tindak pidana pencucian uang tidak secara alternatif, tetapi digabungkan secara kumulatif.

Meskipun telah ada Surat Edaran Jaksa Agung mengenai dakwaan kejahatan asal dan tindak pidanan pencucian uang harus dalam susunan dakwaan kumulatif ternyata dalam praktik masih dijumpai dakwaan yang disusun secara alternatif (Ganarsih, 2016: 95) sehingga tindak pidana pencucian uang tidak dapat dijerat. Pada akhirnya, yang dapat dituntut hanya sebatas tindak pidana awal saja (primary crime), dan pelaku pencucian uang menjadi bebas. Masalah ini merupakan dampak logis karena adanya due process model yang dianut Indonesia dalam menegakkan hukum karena hukum formal sangat dikedepankan, sehingga tindak pidana menjadi penting untuk dibuktikan sebelum melakukan penyidikan ataupun penuntutan terhadap kasus tindak pidanan pencucian uang.

Pandangan tersebut dikarenakan tindak pidana pencucian uang merupakan tindak pidana lanjutan, walaupun tindak pidana pencucian uang merupakan perbuatan yang terpisah dan berdiri sendiri, dan tidak sejenis dengan tindak pidana pokoknya (Sabatini, 2010: 229). Inti dari tindak pidana pencucian uang adalah menikmati atau menggunakan hasil kejahatan asal sehingga bila ada seseorang melakukan kejahatan asal dan kemudian dia melakukan pencucian uang maka seharusnya disangkakan sekaligus atas dua kejahatan tersebut (Ganarsih, 2016: 95). Oleh karena itu sangat tepat susunan dakwaan terhadap LS.

Majelis hakim pada tingkat pertama membebaskan LS dari dakwaan tindak pidana pencucian uang dan menyatakan LS terbukti secara sah dan meyakinkan bersalah melakukan 
tindak pidana "secara bersama-sama dengan sengaja membeli hasil hutan yang diketahui berasal dari kawasan hutan yang diambil secara tidak sah" dan tindak pidana "secara bersamasama melakukan pengangkutan bahan bakar minyak tanpa izin usaha pengangkutan.” Namun di tingkat banding maupun kasasi, LS terbukti secara sah dan meyakinkan bersalah melanggar pasal tindakpidanakehutanan, tindakpidanamigas dan tindak pidana pencucian uang sebagaimana yang didakwakan. Bahkan majelis hakim kasasi, memberikan pemberatan hukuman dari delapan tahun sebagaimana divonis Pengadilan Tinggi Jayapura menjadi lima belas tahun disebabkan adanya peran LS yang mengendalikan korporasi.

Putusan Nomor 1081 K/PID.SUS/2014 memberikan penjelasan hukum bahwa meskipun namanya tidak tercantum dalam akta pendirian perusahaan, namun dalam kenyataannya mempunyai kekuasaan dan kewenangan yang sangat menentukan dalam pengambilan keputusan perusahaan maka dapat ditetapkan sebagai penentu dan pengendali korporasi.

Dasar pertimbangan hukum majelis hakim kasasi memberikan penjeratan atas tindak pidana pencucian uang terhadap LS selaku personel pengendali korporasi yaitu bahwa meskipun nama terdakwa tidak tercantum di dalam akta pendirian perusahaan CV LBT dan UD MR serta PT R, melainkan atas nama orang lain. Namun dalam kenyataannya atau secara de facto terdakwa LS mempunyai kekuasaan dan kewenangan yang sangat signifikan dan sangat menentukan dalam pengambilan keputusan dan kebijakan perusahaan.

Saksi LI menerangkan bahwa setiap kali pengambilan keputusan atau kebijakan perusahaan selalu berkoordinasi dan meminta petunjuk dari terdakwa LS. Terdakwa LS yang menentukan setiap langkah dan keputusan yang akan diambil oleh pimpinan perusahaan. Jadi benar secara legalitas nama yang tercantum dalam akta perusahaan adalah LI, LP, dan SP, tidak ada nama terdakwa LS akan tetapi secara nyata dan de facto terdakwa sebagai penentu dan pengendali perusahaan di lapangan.

Dijelaskan lebih lanjut dalam pertimbangan hukum majelis hakim kasasi bahwa direktur utama dan direktur serta komisaris hanya formalitas belaka. Adapun latar belakang mengapa terdakwa tidak mencantumkan namanya dalam akta perusahaan sebagai pemegang saham disebabkan kedudukan atau posisi terdakwa sebagai anggota Polri yang tidak diperbolehkan melakukan bisnis secara langsung. Namun untuk menghindari larangan ini terdakwa mengambil keuntungan dengan cara mengendalikan perusahaan tidak secara formalitas. Terdakwa dalam mengendalikan perusahaan CV LBT, UD MR, dan PT R tidak secara formalitas, telah melakukan berbagai pelanggaran dan kejahatan yaitu tindak pidana kehutanan, pencucian uang, dan penyelundupan bahan bakar minyak.

Berdasarkan pertimbangan hukum di atas, LS diidentifikasi oleh majelis hakim kasasi sebagai pengendali korporasi meskipun namanya tidak tercantum dalam struktur organisasi. Secara normatif, ketentuan personel pengendali korporasi masih dalam pengertian struktural. Artinya personel pengendali korporasi yang dimaksudkan masih masuk dalam koridor sebuah otoritas dan kapasitas pengurus sebagaimana frasa "otorisasi dari atasannya" dalam pengertian Pasal 1 Nomor 14 menyebutkan: "Personel pengendali korporasi adalah setiap orang yang memiliki kekuasaan atau wewenang sebagai penentu kebijakan korporasi atau memiliki kewenangan 
untuk melakukan kebijakan korporasi tersebut tanpa harus mendapat otorisasi dari atasannya." Dari perumusan tersebut, secara eksplisit tidak ada penjelasan lebih lanjut tentang kriteria pengendali korporasi yang tidak masuk dalam struktur kepengurusan korporasi.

Pernyataan "tanpa harus mendapat otorisasi atasannya" ini menunjukkan bahwa kedudukan personel pengendali tersebut masih dalam struktur organisasi korporasi karena bertolak pada frasa "otoritas." Perihal pertanggungjawaban teknisnya diatur oleh Pasal 6 ayat (1) UndangUndang Pencegahan dan Pemberantasan Tindak Pidana Pencucian Uang yaitu dalam hal tindak pidana pencucian uang dilakukan oleh korporasi, pidana dijatuhkan terhadap korporasi dan/atau personel pengendali korporasi. Dalam penjelasannya, korporasi mencakup juga kelompok yang terorganisasi yaitu kelompok terstruktur yang terdiri dari tiga orang atau lebih, yang eksistensinya untuk waktu tertentu, dan bertindak dengan tujuan melakukan satu atau lebih tindak pidana yang diatur dalam undangundang dengan tujuan memperoleh keuntungan finansial atau non-finansial baik secara langsung maupun tidak langsung. Secara eksplisit masih mengemukakan pertanggungjawaban pidana yang bersifat ter"struktur" terhadap pengendali korporasi.

\section{Berkaitan dengan korporasi yang} merupakan badan hukum, yang terbentuk secara struktural dan memiliki susunan anggota yang jelas. Hal itu menjadi faktor sulitnya penetapan “orang" dalam korporasi untuk ditetapkan sebagai terdakwa mewakili korporasi atau ditetapkan sebagai personel pengendali korporasi (Heryndra, 2014: 15). Pada dasarnya personel pengendali korporasi memiliki kewenangan tertinggi menurut struktur organisasi dalam sebuah korporasi, sehingga dalam setiap perbuatannya tidak diharuskan untuk mendapat izin dari pihak yang lain, sebagai contoh, pemilik saham mayoritas. Keterlibatan dari seorang personel pengendali korporasi dalam sebuah korporasi baik terkait perbuatan hukum maupun bukan perbuatan hukum yang berkaitan dengan korporasi, selalu diwakilkan kehadirannya oleh seorang pengurus dalam sebuah korporasi (Heryndra, 2014: 17-18). Undang-undang hanya mengkonstruksikan pertanggungjawaban pidana yang bersifat ter"struktur" terhadap pengendali korporasi sedangkan pengendali korporasi yang "tidak tercantum" dalam kepengurusan masih belum dijelaskan atau teridentifikasi secara eksplisit.

Mahkamah Agung dalam perkara LS telah melakukan penafsiran hukum guna menjatuhkan putusan pemidanaan terhadap pengendali korporasi yang tidak tercantum dalam kepengurusan. Dipermasalahkannya LS sebagai personel pengendali korporasi meskipun tidak tercantum dalam struktur kepengurusan adalah dengan terbuktinya semua uang dari hasil transaksi penjualan dan pengiriman bahan bakar minyak masuk ke rekening LS.

Secara de jure, LS tidak bertindak sebagai direktur atau manajer keuangan yang bertugas menerima uang dari hasil pengelolaan perusahaan. Di satu sisi menjelaskan secara faktual bahwa otak atau directing mind and will korporasi-korporasi tersebut adalah ada pada diri LS sehingga tidak saja yang bersifat kewenangan dan kekuasaan pengelolaan kepengurusan korporasi, tetapi dalam hal transaksi keuangan, LS juga turut berperan sangat penting. Adalah tepat yang disebutkan oleh majelis hakim kasasi bahwa kepengurusan korporasi yaitu direktur beserta jajarannya hanya merupakan "boneka" 
dari LS untuk melakukan berbagai tindak pidana. Bahkan dari hasil tindak pidana tersebut, LS juga melakukan penampungan dan mencuci uangnya melalui korporasi-korporasi tersebut.

Modus operandi dengan cara mendirikan korporasi dan menempatkan orang-orang dalam kepengurusannya sebagai boneka sudah mulai marak terjadi. Hal ini dikenal dengan criminal corporations yaitu korporasi yang sengaja dibentuk dan dikendalikan untuk melakukan kejahatan. Korporasi di sini hanya ditempatkan sebagai sarana untuk melakukan kejahatan, atau sebagai "topeng" untuk menyembunyikan wajah asli dari suatu kejahatan tersebut. Pemimpin korporasi di sini hanya melaksanakan tugas berdasarkan pembagian pekerjaan yang telah ditentukan oleh para penjahat yang membuat korporasi dengan tujuan menutupi kejahatan tersebut (Hiariej, 2014: 157).

Ironisnya, posisi personel pengendali korporasi yang "tidak masuk" secara struktural kepengurusan, belum dijelaskan secara eksplisit sebagai kriteria pengendali korporasi oleh perundang-undangan yang ada. Putusan Nomor $1081 \mathrm{~K} / \mathrm{PID}$. SUS/2014 maka berpotensi menjadi preseden hukum dalam menetapkan pemidanaan terhadap personel pengendali korporasi yang tidak tercantum dalam kepengurusan korporasi.

Layaknya Putusan Nomor 1081 K/PID. SUS/2014 ini dijadikan yurisprudensi dalam rangka efektivitas penanggulangan tindak pidana korporasi khususnya berkaitan dengan kedudukan personel pengendali yang tidak tercantum dalam kepengurusan organisasi korporasi. Hal ini disebabkan bahwa pada dasarnya directing mind dari korporasi tidak hanya dimiliki oleh orang-orang yang menduduki jabatan secara yuridis formal, melainkan juga orang-orang yang dalam kenyataannya melakukan operasionalisasi korporasi. Orang-orang tersebut tidak memiliki kewenangan apapun secara yuridis formal dalam melakukan pengelolaan korporasi, namun orang-orang inilah yang sebenarnya melakukan pengendalian terhadap setiap perbuatan dan keputusan yang diambil oleh orang-orang yang secara yuridis formal melakukan pengurusan korporasi (Alim et al., 2013: 63).

Selain kaidah hukum perluasan pengertian personel pengendali korporasi di luar struktur kepengurusan korporasi, Putusan Nomor 1081 K/PID.SUS/2014 yang menyatakan LS sebagai pengendali korporasi ini juga dapat ditindaklanjuti oleh penegak hukum untuk memproses korporasi-korporasi yang dikendalikan oleh LS dengan dakwaan tindak pidana korporasi. Artinya setelah putusan pemidanaan terhadap LS sudah berkekuatan hukum tetap, maka terhadap korporasinya bisa dilakukan penuntutan dan pertanggungjawaban pidana. Sebagaimana dalam perkara PT GJW yang terlibat dalam tindak pidana korupsi misalnya, di mana direktur utamanya terlebih dahulu diproses pemidanaannya sampai dengan berkekuatan hukum tetap dan kemudian dilanjutkan terhadap korporasinya dituntutkan pertanggungjawaban pidananya.

Pertimbangan hukum pada Putusan Nomor 812/PID.SUS/2010/PN.Bjm dijelaskan bahwa apabila dihubungkan dengan Pasal 20 ayat (1) Undang-Undang Tindak Pidana Korupsi yang berbunyi bahwa dalam hal tindak pidana korupsi dilakukanolehatauatasnamasuatukorporasimaka tuntutan dan penjatuhan pidana dapat dilakukan terhadap korporasi dan atau pengurusnya, kata dan dalam kalimat tersebut menunjukkan bahwa undang-undang mengatur adanya lebih dari satu pelaku yang dapat dikenakan dalam satu tindak pidana korupsi, yaitu orang/person yang menjadi 
directing mind daripada korporasi tersebut maupun korporasi itu sendiri yang dalam hal ini diwakili oleh SW selaku direktur utamanya, oleh karenanya walaupun terhadap SW telah dinyatakan bersalah dan dijatuhi hukuman atas tindak pidana korupsi namun PT GJW selaku korporasi yang terlibat di dalamnya juga dapat dimintai pertanggungjawaban atas kesalahan/ penyimpangan yang telah dilakukan.

Berdasarkan pertimbangan hukum tersebut, PT GJW dinyatakan oleh majelis hakim Pengadilan Negeri Banjarmasin telah terbukti bersalah melanggar Pasal 2 ayat (1) jo. Pasal 18 jo. Pasal 20 Undang-Undang Tindak Pidana Korupsi jo. Pasal 64 ayat (1) KUHP dan menjatuhkan pidana terhadap terdakwa PT GJW dengan pidana denda sebesar Rp1.300.000.000,- serta pidana tambahan berupa penutupan sementara PT GJW selama enam bulan.

Bercermin dari perkara PT GJW ini, bahwa berbagai kasus korupsi yang melibatkan korporasi sebagai sarana merugikan negara, di antaranya secara jelas mengemukakan keterkaitan pendirian atau pengelolaan korporasi yang bertujuan dan dimaksudkan untuk memperoleh keuntungan dari proyek-proyek pemerintahan yang sengaja dimanipulasi dan dikorupsi dengan berbagai modus operandi. Sayangnya meskipun telah diputus pemidanaan terhadap pengurusnya yang terbukti telah melakukan perbuatan merugikan keuangan negara dan bahkan sampai putusan tersebut berkekuatan hukum tetap, tak kunjung dilakukan proses penuntutan dan pemidanaan terhadap korporasinya.

Kaidah hukum dari pemidanaan putusan Pengadilan Negeri Banjarmasin ini dapat menjadi preseden yang baik bagi upaya pemberantasan korupsi di negeri ini khususnya terkait dengan efektivitas pemidanaan terhadap korporasi sebagai pelaku a quo pertanggungjawabannya atas terjadinya tindak pidana korupsi. Jadi begitu pengurusnya yang berposisi sebagai directing mind telah terbukti bersalah melakukan tindak pidana korupsi dan dipidana karenanya sesuai putusan pengadilan yang berkekuatan hukum tetap, maka terhadap korporasinya harus dituntut dan diproses pertanggungjawaban pidananya di hadapan peradilan tindak pidana korupsi (Suhariyanto, 2016: 202).

Undang-Undang Pencegahan dan Pemberantasan Tindak Pidana Pencucian Uang memang telah menerima korporasi sebagai subjek hukum pidana, terdapat beberapa kasus yang mengindikasikan keterlibatan korproasi yang melakukan praktik pencucian uang di Indonesia, akan tetapi pada tahap penyelesaiannya dalam sistem peradilan pidana belum ada satupun korporasi yang dijerat dan dikenai sanksi pidana (Andika, 2012: 149). Apalagi perkara yang terkait dengan penjeratan korporasi yang dilekatkan pada kesalahan personel pengendali korporasi adalah tidak mudah dilakukan karena persyaratan yang sifatnya harus kumulatif dan juga biasanya motivasi dilakukan kejahatan tindak pidana pencucian uang tersebut tidak pernah lepas dari pertimbangan kepentingan atau keuntungan pribadi sang pelaku. Namun demikian dimungkinkan terjadi tindak pidana tersebut dimotivasi oleh kepentingan pribadi yang mengatasnamakan korporasi (Muslim \& Nasution, 2011: 6-7).

Keterkaitan antara pengurus korporasi dan korporasi itu sendiri sangat erat sehingga agak sulit untuk mengidentifikasi perbuatan mana yang dilakukan oleh pengurus korporasi dalam rangka untuk mencapai tujuan korporasi dengan perbuatan mana yang dilakukan oleh pengurus 
dalam rangka untuk kepentingan pengurus korporasi itu sendiri (Andika, 2012: 142).

Berdasarkan kaidah hukum pada putusan perkara PT GJW di atas, bahwa meskipun terhadap LS sudah dijatuhkan putusan pemidanaan yang berkekuatan hukum tetap, bukan berarti terhadap korporasi-korporasi yang dikendalikannya bisa bebas dan bersih sehingga tidak perlu dibebankan pertanggungjawaban pidana dan pemidanaan yang serupa. Mengingat Pasal 6 ayat (1) UndangUndang Pencegahan dan Pemberantasan Tindak Pidana Pencucian Uang bahwa "dalam hal tindak pidana pencucian uang sebagaimana dimaksud Pasal 3, Pasal 4, dan Pasal 5 dilakukan oleh korporasi, pidana dijatuhkan terhadap korporasi dan/atau personel pengendali korporasi."

Frasa "dan/atau" telah menegaskan bahwa keduanya dapat dibebankan pertanggungjawaban pidana secara sendiri-sendiri. Artinya ketika tindak pidana pencucian uang dilakukan dengan korporasi maka pemidanaan dapat dijatuhkan kepada pengendali korporasi dan pemidanaan terhadap pengendali korporasi tersebut tidak menghilangkan pertanggungjawaban pidana korporasinya. Demikian juga sebaliknya. Jadi begituLS dinyatakan sebagaipengendalikorporasi (meski tak tercantum dalam kepengurusan) telah dipidana maka terhadap korporasinya juga dapat diproses pemidanaannya.

Menurut Pasal 6 ayat (2) Undang-Undang Pencegahan dan Pemberantasan Tindak Pidana PencucianUangbahwa pidana dijatuhkan terhadap korporasi apabila tindak pidana pencucian uang itu: a) Dilakukan atau diperintahkan oleh personel pengendali korporasi; b) Dilakukan dalam rangka pemenuhan maksud dan tujuan korporasi; c) Dilakukan sesuai dengan tugas dan fungsi pelaku atau pemberi perintah; dan d)
Dilakukan dengan maksud memberikan manfaat bagi korporasi. Terpenuhinya Pasal 6 ayat (2) tersebut secara kumulatif sudah bisa diterapkan pada korporasi-korporasi yang dikendalikan oleh LS karena secara fakta di persidangan dan dibenarkan oleh putusan hakim bahwa LS adalah pengendali korporasi meskipun dirinya tidak tercantum dalam kepengurusan.

Pengendalian LS atas korporasi-korporasi tersebutadalah dalamrangkamenjalankanmaksud dan tujuan pendirian korporasi serta memberikan manfaat bagi korporasi. Bahkan dijelaskan oleh para saksi yang bertindak dan berkedudukan sebagai direktur tersebut bahwa LS adalah pemilik kewenangan dan pemegang perintah secara fungsional atas korporasi. Kesengajaan LS mendesain korporasi sedemikian rupa hingga pelaksanaan roda organisasi korporasi selayaknya "boneka" dalam melakukan kejahatan. Tentu hasil tindak pidana yang ada, bukan saja mengalir kepada LS secara pribadi, tetapi juga mengalir atas nama dan menguntungkan korporasi secara institusional maupun personal jajaran direksinya.

Friedmann, dalam hubungannya dengan penerapan sanksi pidana terhadap korporasi mengemukakan bahwa "the main effect and usefulness of criminal conviction impose upon a corporation cannot be seen either in any personal injury or in most cases in the financial detriment, but in the public approbrium and stigma that attaches to a conviction (Pramono, 2013: 180). Adapun Clinard \& Yeager menyatakan bahwa terdapat beberapa kriteria kapan seharusnya sanksi pidana diarahkan pada korporasi yaitu di antaranya:

1. The degree of loss to the public.

2. The level of complicity by high corporate managers. 
3. The duration of the violation.

4. The frecuency of the violation by the corporation.

5. Evidence of intent to violate.

6. Evidence of extortion, as in bribery cases.

7. The degree of notoriety engendered by the media.

8. Precedent in law.

9. The history of serious violations by the corporation.

\section{Deterrence potential.}

11. The degree of corporation evidence by the corporation (Clinard \& Yeager, 1980: 90).

Secara teoritis, pertanggungjawaban pidana korporasi yang dikendalikan oleh LS dapat didasarkan atas teori identifikasi, di mana menurut teori ini untuk dapat membebankan pertanggungjawaban pidana kepada suatu korporasi, siapa yang melakukan tindak pidana tersebut harus dapat diidentifikasi oleh penuntut umum. Apabila tindak pidana itu dilakukan oleh directing mind (otak) dari korporasi maka pertanggungjawaban tindak pidana itu baru dibebankan kepada korporasi. Yang artinya, untuk dapat menarik korporasi tersebut haruslah merupakan directing mind (otak) dari korporasi atau dalam hal ini mempunyai wewenang untuk melaksanakan tugas dan kewajiban dalam rangka pemenuhan kepentingan korporasi (Andika, 2012: 142).

Secara jelas dan lugas dinyatakan oleh majelis hakim kasasi, bahwa LS adalah orang yang mengendalikan perusahaan dan jajaran pengurus korporasi tidak dapat untuk "tidak mengindahkan" perintah atau arahan dari LS. Dengan pernyataan bahwa pengurus korporasi hanya "boneka" LS dalam mengarahkan korporasi untuk dijadikan sebagai sarana melakukan tindak pidana maka sudah tentu secara faktual LS adalah directing mind and will dari korporasi. Dengan demikian korporasi yang digunakan sebagai sarana oleh LS tersebut dapat dituntutkan pertanggungjawaban pidana.

Berdasarkan uraian penjelasan masuknya unsur-unsur Pasal 6 ayat (2) dan perspektif teori identifikasi di atas, maka sudah seharusnya penegak hukum segera memeriksa dan menetapkan korporasi-korporasi yang diuntungkan dan dalam pengendalian LS. Jika pemidanaan hanya dituntutkan pada LS selaku personel pengendali korporasi dan tidak terhadap korporasinya yang notabene juga diuntungkan, maka akan tidak adil bagi negara dan masyarakat yang notabene telah dirugikan atas "menguapnya" aset hasil tindak pidana yang dicuci "dengan menggunakan" korporasinya. Dalam rangka pengembalian kerugian negara, maka sudah selayaknya korporasinya dituntutkan pertanggungjawaban pidananya juga atas tindak pidana pencucian uang. Oleh karena itu relevan jika LS setelah mendapatkan pemidanaan, maka penegak hukum memproses korporasinya untuk dituntutkan pertanggungjawaban pidana.

Selain bertujuan untuk memburu atau mengembalikan aset hasil tindak pidana yang telah di atas-namakan korporasi, juga secara preventif memberikan pencegahan agar korporasi-korporasi tersebut melakukan kembali tindak pidana dan peringatan kepada korporasikorporasi yang selama ini telah digunakan sebagai sarana pencucian uang oleh para personel pengendalinya (yang tidak tercantum dalam kepengurusan). Sebagaimana tujuan dari 
kriminalisasi tindak pidana pencucian uang yaitu berorientasi pada pemidanaan kejahatan penyamaran atau penyembunyian hasil tindak pidana, oleh karena itu sangat penting penindakan terhadap korporasi yang dikendalikan LS tersebut guna efektivitas penanggulangan tindak pidana pencucian uang.

\section{KESIMPULAN}

Secara normatif, undang-undang mengkonstruksikan pertanggungjawaban pidana yang bersifat ter"struktur" terhadap pengendali korporasi sebagaimana kalimat "tanpa harus mendapat otorisasi atasannya" yang terdapat dalam definisi personel pengendali korporasi Pasal 1 angka 4 Undang-Undang Pencegahan dan Pemberantasan Tindak Pidanan Pencucian Uang. Pengaturan pengendali korporasi yang "tidak tercantum" dalam kepengurusan masih belum dijelaskan atau teridentifikasi.

Melalui Putusan Nomor 1081 K/PID. SUS/2014, Mahkamah Agung memberikan penafsiran terhadap pengendali korporasi yang berada di luar struktur organisasi. Mahkamah Agung menjatuhkan pidana terhadap LS karena dinilai sebagai pengendali korporasi, meskipun yang bersangkutan tidak tercantum dalam struktur kepengurusan. Dipermasalahkannya LS sebagai personel pengendali korporasi meskipun tidak tercantum dalam struktur kepengurusan adalah dengan terbuktinya semua uang dari hasil transaksi penjualan dan pengiriman bahan bakar minyak ilegal masuk ke rekening LS dan secara de facto ternyata segala pengambilan keputusan korporasi diwenangi oleh LS. Padahal secara de jure, LS tidak bertindak sebagai pengurus korporasi. Fakta ini menjelaskan bahwa otak atau directing mind and will korporasi tersebut adalah ada pada diri LS. Kepengurusan korporasi yaitu direktur beserta jajarannya hanya merupakan "boneka" dari LS untuk melakukan berbagai tindak pidana.

\section{SARAN}

Putusan Nomor 1081 K/PID.SUS/2014 berpotensi menjadi preseden hukum dalam menetapkan pemidanaan terhadap personel pengendali korporasi yang tidak tercantum dalam kepengurusan korporasi. Layaknya Putusan Nomor 1081 K/PID.SUS/2014 ini dijadikan yurisprudensi dalam rangka efektivitas penanggulangan tindak pidana korporasi khususnya berkaitan dengan kedudukan personel pengendali yang tidak tercantum dalam kepengurusan organisasi korporasi. Selain kaidah hukum perluasan pengertian personel pengendali korporasi di luar struktur kepengurusan korporasi, Putusan Nomor 1081 K/PID.SUS/2014 yang menyatakan LS sebagai pengendali korporasi ini juga dapat ditindaklanjuti oleh penegak hukum untuk memproses korporasi-korporasi yang dikendalikan oleh LS dengan dakwaan tindak pidana korporasi.

Artinya setelah putusan pemidanaan terhadap LS sudah berkekuatan hukum tetap, maka terhadap korporasinya bisa dilakukan penuntutan dan pertanggungjawaban pidana. Jika pemidanaan hanya dituntutkan pada LS selaku personel pengendali korporasi dan tidak terhadap korporasinya yang notabene juga diuntungkan, maka akan tidak adil bagi negara dan masyarakat yang notabene telah dirugikan atas "menguapnya" aset hasil tindak pidana yang dicuci "dengan menggunakan" korporasinya. Dalam rangka pengembalian kerugian negara, maka sudah selayaknya korporasinya dituntutkan 
pertanggungjawaban pidananya juga atas tindak pidana pencucian uang.

\section{DAFTAR ACUAN}

Alim, H. et al. (2013). Pemidanaan korporasi atas tindak pidana korupsi di Indonesia. Yogyakarta: Pusat Kajian Antikorupsi Fakultas Hukum Universitas Gadjah Mada.

Amalia, R. (2016, Desember). Pertanggungjawaban korporasi dalam tindak pidana pencucian uang menurut hukum Islam. Jurnal Al Jinayah, 2 (2), 388-407.

Andika, A. (2012). Pertanggungjawaban pidana korporasi pada tindak pidana pencucian uang. Tesis. Jakarta: Fakultas Hukum Program Pasca Sarjana Universitas Indonesia.

Atmasasmita, R. (2014). Hukum kejahatan bisnis: Teori \& praktik di era globalisasi. Jakarta: Kencana.

Clinard, M.B., \& Yeager, P.C. (1980). Corporate crime. London: Collar Macmillen.

Dix, G.E., \& Gilbert. (1979). Law summeries criminal law. New York: Harcourt Brace Jivanivich Legal \& Profesional Publications.

Eddyono, S.W. (2017). Dari 'lacak kayu bulatnya'ke 'lacak uangnya'. Jakarta: Institute for Criminal Justice Reform.

Efendy, M. (2012). Diskresi, penemuan hukum, korporasi tax amnesty dalam penegakan hukum. Jakarta: Referensi.

Ganarsih, Y. (2016). Penegakan hukum anti pencucian uang dan permasalahannya di Indonesia. Jakarta: Rajawali Pers.
Ginting, S. (2012, Oktober). Kebijakan pemidanaan korporasi dalam tindak pidana pencucian uang. Jurnal Magister Hukum Udayana, 1(1), 1-20.

Handoko, D. (2015). Hukum positif mengenai hak kekayaan intelektual di Indonesia (Jilid II). Jakarta: Hawa \& Ahwa.

Heryndra, M.F. (2014, Juni). Kajian yuridis kriteria tentang "personel pengendali korporasi" terkait pertanggungjawaban pidana korporasi berdasarkan Pasal 6 ayat (1) Undang-Undang Nomor 8 Tahun 2010 tentang Pencegahan dan Pemberantasan Tindak Pidana Pencucian Uang. Jurnal Mahasiswa Fakultas Hukum. Diakses dari http://hukum.studentjournal.ub.ac.id

Hiariej, E.O.S. (2014). Prinsip-prinsip hukum pidana. Yogyakarta: Cahaya Atma Pustaka.

Kristian. (2014). Hukum pidana korporasi: Kebijakan integral (Integral policy) formulasi pertanggungjawaban pidana korporasi di Indonesia. Bandung: Nuansa Aulia.

Kristiana, Y. (2015). Pemberantasan tindak pidana pencucian uang: Perspektif hukum progresif. Yogyakarta: Thafa Media.

Manthovani, R. (2013). Penuntutan korporasi sebagai pelaku tindak pidana dalam kejahatan di sektor kehutanan: Optimalisasi penggunaan UndangUndang Pencucian Uang dalam pembuktian tindak pidana di sektor kehutanan di Indonesia yang dilakukan oleh korporasi. Diakses dari http://www.antikorupsi.org

Mugopal, U. (2016, November 15). Pertanggungjawaban pidana korporasi dalam tindak pidana korupsi (Persoalan dalam praktik). Makalah disampaikan dalam seminar tentang "Kedudukan dan Tanggung Jawab Korporasi dalam Tindak Pidana Korupsi." Jakarta: Mahkamah Agung Badiklat Hukum dan Peradilan. 
Mulyadi, L. (2010). Seraut wajah putusan hakim dalam Hukum Acara Pidana Indonesia: Perspektif praktis, teoritis, teknik membuatnya \& permasalahannya. Bandung: Citra Aditya Bhakti.

Muslim, F., \& Nasution, E. (2011, November 19). Menjerat koruptor dengan Undang-Undang Tindak Pidana Pencucian Uang. Makalah disampaikan pada seminar nasional dan dialog interaktif dengan tema "Apa dan Mengapa Tindak Pidana Korupsi dan Pencucian Uang Merajalela." Padang: Lembaga Pengabdian Masyarakat (LPKM) Universitas Negeri Padang bekerjasama dengan Pro Justitia Institute Jakarta dan Harian Umum Singgalang.

Panggabean, H.P. (2014). Penerapan teori hukum dalam sistem peradilan Indonesia. Bandung: Alumni.

Panggabean,M.L.(2017, Maret). Pertanggungjawaban korporasi dalam hukum pidana: Kajian Putusan No. 1405 K/Pid.Sus/2013. Jurnal Dictum, 12, $3-24$.

Pramono, W. (2013). Pertanggungjawaban pidana korporasi hak cipta. Bandung: Alumni.

Sabatini, H. (2010, Desember). Implementasi Undang-Undang Tindak Pidana Pencucian Uang (TPPU) di Indonesia (Suatu gambaran tentang pengetahuan dana aplikasi aparat penyidik penuntut umum dan PPATK). Jurnal Kriminologi Indonesia, 6(III), 216-231.

Sjahdeni, S.R. (2006). Pertanggungjawaban pidana korporasi. Jakarta: Grafiti Pers.

Sjawie, H.F. (2013). Direksi Perseroan Terbatas serta pertanggungjawaban pidana korporasi. Bandung: Citra Aditya Bhakti.

Sudirman, L., \& Feronica. (2011, Juni). Pembuktian pertanggungjawaban pidana lingkungan \& korupsi korporasi di Indonesia \& Singapura. Jurnal Mimbar Hukum, 23 (2), 237-429.

Suhariyanto, B. (2016, Juni). Progresivitas putusan pemidanaan terhadap korporasi pelaku tindak pidana korupsi. Jurnal De Jure, 116(2), 2012013.

Sutedi, A. (2015). Buku pintar hukum perseroan terbatas. Jakarta: Raih Asa Sukses.

Tambunan, M.P. (2016, Januari-Juli). Pertanggungjawaban pidana korporasi dalam tindak pidana pencucian uang. Jurnal mimbar Keadilan, 111-128. Diakses dari http://jurnal. untag-sby.ac.id 